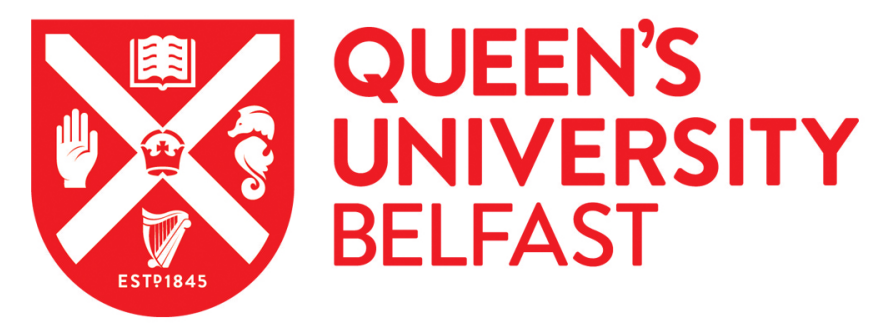

\title{
Land markets and the morcellation of holdings in pre-plague England and pre-famine Ireland
}

Campbell, B. (2013). Land markets and the morcellation of holdings in pre-plague England and pre-famine Ireland. In G. Béaur, P. R. Schofield, J-M. Chevet, \& M-T. Pérez-Picazo (Eds.), Property rights, land markets and economic growth in the European countryside (13th-20th centuries) (pp. 197-218). [9] (Rural History in Europe (RURHE)). Brepols Publishers. http://www.brepols.net/Pages/ShowProduct.aspx?prod_id=IS9782503529554-1

Published in:

Property rights, land markets and economic growth in the European countryside (13th-20th centuries)

\section{Document Version:}

Publisher's PDF, also known as Version of record

\section{Queen's University Belfast - Research Portal:}

Link to publication record in Queen's University Belfast Research Portal

\section{Publisher rights}

Copyright Brepols 2017. This work is made available online in accordance with the publisher's policies. Please refer to any applicable terms of use of the publisher.

\section{General rights}

Copyright for the publications made accessible via the Queen's University Belfast Research Portal is retained by the author(s) and / or other copyright owners and it is a condition of accessing these publications that users recognise and abide by the legal requirements associated with these rights.

Take down policy

The Research Portal is Queen's institutional repository that provides access to Queen's research output. Every effort has been made to ensure that content in the Research Portal does not infringe any person's rights, or applicable UK laws. If you discover content in the Research Portal that you believe breaches copyright or violates any law, please contact openaccess@qub.ac.uk. 


\title{
9. Land markets and the morcellation of holdings in Pre-Plague England and Pre-Famine Ireland
}

\author{
Bruce M. S. CAMPBELL
}

\section{Introduction}

To economists it is axiomatic that 'markets for labour, land, and capital play important roles in the long-term evolution of economies' (van Bavel, de Moor \& van Zanden, 2009). Once such markets had come into being, it is held, the path was opened for reallocation of the factors of production to those able to use them most efficiently. Within agriculture this paved the way for the eventual emergence of agrarian capitalism, whereby large-scale producers well supplied with capital engrossed holdings on which hired labour was employed to produce surpluses for profit: labour superfluous to this task was dispossessed of land and displaced out of agriculture into other economic activities (Hoppe \& Langton, 1994; Whittle, 2000; Hoppenbrouwers \& van Zanden, 2001). In England the origin of modern factor markets can be dated to the two centuries of vigorous commercialisation that preceded the Black Death of 1348-1349 (Campbell, 2009). An active market in labour appears to have developed first and was well established by the end of the twelfth century. Evolution of a market in land followed the legal reforms initiated by Henry II in the 1160s and 1170s, which severed the established feudal connection between land holding and personal obligation and created legally secure and defensible property rights in land. Thenceforth, first freehold land and then villein land (un-free land, exempt from the jurisdiction of the royal courts and originally held by servile tenants in return for money and labour rents) were bought and sold with increasing frequency. This had a galvanising effect upon the growth of a capital market, since land now became a security against which credit could be secured (Palmer, 1985). Moreover, as, in an inflationary and ever more resource-scarce age, land became an appreciating asset, so men increasingly borrowed in order to acquire land.

In England there was nevertheless a pronounced lag between the establishment of well-developed factor markets (which had been achieved by the close of the thirteenth century) and the transition to modern economic growth, which commenced over three centuries later (Allen, 2000 and 2001, for evidence of the timing of this transition). An interval of such duration is not easily reconciled with the notion that the existence of land markets should have led directly to the emergence of agrarian capitalism. This 
is because, under conditions of economic expansion, rising prices, and increasing population, land markets were as, if not more, likely to lead to the morcellation as to the engrossment of holdings (Bekar \& Reed, 2009). By matching the supply of land to the expanding demand for it, land markets may actually have endorsed rather than eliminated a subsistence-producing peasantry on the land. The latter substituted labour, of which they had no shortage, for capital, in which they were deficient, with potentially adverse consequences for the productivity of labour, especially as the supply of labour rose in excess of demand. The Ricardian and Malthusian tendencies inherent within all pre-industrial societies were thereby reinforced and the transition to modern economic growth frustrated.

Bas van Bavel has drawn attention to the 'strong fragmentation' of farms that arose in both commercialised Holland and Flanders during the early modern period and the relative rarity of farm agglomeration at that time (van Bavel, 2001: 31-32). Examples of the latter certainly occurred - for example in parts of eastern England and in the Dutch river area from the sixteenth century on - but on current knowledge these appear to be more the exception than the rule (Whittle, 2000; van Bavel, 2001: 31-32). Elsewhere, morcellation predominated and peasantries and smallholding proto-industrialists persisted. The historical challenge, of course, as R. H. Tawney (1912) long ago recognised, is to understand and explain when and how, in much of Western Europe, the exception eventually became the rule and agglomeration finally prevailed. Holland and much of England were the first to exhibit the rising total factor productivity in agriculture that is symptomatic of a transition to agrarian capitalism, but across most of the rest of the continent that breakthrough seems to have been a comparatively recent phenomenon (Allen, 2000). Until this late transformation, it is the premise of this paper that land markets were often instrumental in creating the very property structures and relations on the land most likely to thwart the emergence of agrarian capitalism through perpetuation of labour- rather than capital-intensive methods of production. In its most extreme manifestations, as exemplified by PrePlague England and Pre-Famine Ireland, this resulted in structurally entrenched rural poverty of the most intractable kind.

\section{Large 'capitalist' versus small 'subsistence' producers in Pre-Plague England and Pre-Famine Ireland}

Five centuries and the Irish Sea separate Pre-Plague England (i.e. England from the 1270s to 1340s) from Pre-Famine Ireland (i.e. Ireland from the 1770s to 1840s), yet both exemplify the pre-modern agrarian phenomenon of a proliferating number of ever-smaller land holdings. The upshot, for both societies, was a deepening economic crisis as a growing proportion of rural households experienced a serious 
erosion of their material living standards. In Pre-Famine Ireland the wages paid to general labourers in 'prosperous' County Armagh purchased 8 per cent less oats in the early 1840s than they had done in the early 1750s (calculated from Kennedy, Dowling, 1997: 94-101). In Pre-Plague England the erosion of real wages was even more pronounced. The purchasing power of the daily wage of an English agricultural worker fell by between a quarter and a third during the second half of the thirteenth century and during the famine decade of the 1310 s eroded to only 62 per cent the level it had been in the 1250s (Clark, 2007). Although in both situations the momentum of population growth eventually slowed, the build up of population pressure upon the land was only finally relieved by a massive demographic haemorrhage. An estimated 10 per cent of England's population perished during the Great European Famine of 1315-1321 and at least a further 30 per cent during the Black Death of 1348-1349: by 1377 the population had shrunk to barely half the 1315 total (available estimates of English population in the fourteenth century are reviewed in Campbell, 2000: 399410). Ireland, in turn, lost almost a quarter of its population during the Great Famine of 1845-1851 - half from emigration and the remainder from a combination of starvation and disease - and by 1901 continuing emigration had reduced the population to little more than half its 1845 total (Ó Gráda, 1994: 178-186, 213-35). It was only in the aftermath of these great crises that the process of morcellation was halted and reversed. This was aided by the absence of any marked demographic recovery until the 1460s in Post-Plague England and 1960s in Post-Famine Ireland. Even so, undoing the fragmentation created during the previous eras of population growth proved to be an extremely protracted process.

In 1845 , at its Pre-Famine peak, Ireland's population probably numbered just under $8 \frac{1}{2}$ million, 80 per cent of whom lived on the land (i.e. $63 / 4$ million, or 1.1 million households). Pre-Plague England's population also attained its peak on the eve of a major famine - the Great European Famine of 1315-1321 - when it is likely to have numbered $4 \frac{1}{4}-43 / 4$ million (although some historians would put the figure as high as 5-6 million), 85 per cent of whom lived on the land (i.e. approximately 33/4 million, or $3 / 4$ million households) (Campbell, 2008). 30 years later, on the eve of the Black Death, the population is unlikely to have been greater. For Ireland the anatomy of land holdings in 1845 can be reliably reconstructed from the 1841 census and information collected for poor law purposes around the same time (Bourke, 1993; Ó Gráda, 1993: 78). A corresponding reconstruction of the anatomy of land holdings in England in 1315 is unavoidably more hypothetical, since, although there is a wealth of detailed information on the ownership and occupancy of land, none of it is national in scope (Campbell, 2008: 40). 
Table 9.1. Comparative farm structures: Ireland, 1845 and England, 1315

\begin{tabular}{|c|c|c|c|c|c|c|c|c|}
\hline Ireland 1845: & $\begin{array}{c}\text { Mean } \\
\text { hectares }\end{array}$ & Number & \multicolumn{3}{|c|}{$\begin{array}{c}\% \\
\text { number }\end{array}$} & \multicolumn{3}{|c|}{$\%$ area } \\
\hline & 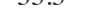 & & $J$ & & & & 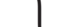 & \\
\hline Strong farmers & 20.0 & 100,000 & 6 & 了 & 22 & 33 & & 85 \\
\hline Family farmers & 8.0 & 200,000 & 13 & J & & 26 & & \\
\hline Poor farmers & 2.0 & 250,000 & 16 & & 79 & 8 & & 15 \\
\hline Cottiers, labourers & 0.4 & $1,000,000$ & 63 & 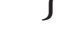 & & 7 & & \\
\hline Ireland 1845 total & 4.2 & $1,600,000$ & 100 & & & 100 & & \\
\hline England 1315: & & & & & & & & \\
\hline Landowners & 42.0 & 20,000 & 3 & 1 & & 19 & ) & \\
\hline Substantial tenants & 25.0 & 10,000 & 1 & 了 & 23 & 6 & \} & 65 \\
\hline Yardlanders & 12.5 & 140,000 & 19 & J & & 40 & J & \\
\hline Smallholders & 5.0 & 250,000 & 33 & ) & 77 & 29 & \} & 35 \\
\hline Cottagers, labourers & 1.0 & 330,000 & 44 & $\int$ & 1 & 6 & & 50 \\
\hline England 1315 total & 5.8 & 750,000 & 100 & & & 100 & & \\
\hline
\end{tabular}

Sources. Ó GRÁDA (1993: 78); CAMPBELL (2007: 45).

As will be noted from Table 9.1, neither Pre-Famine Ireland nor Pre-Plague England lacked substantial 'capitalist' farms producing in excess of the subsistence needs of their households. In Ireland 'wealthy', 'strong', and the largest 'family' farmers accounted for about one eighth of all occupying tenants and held an impressive 70 per cent of the land. In England landlords managing their estates directly, substantial tenants, and yardlanders comprised almost a quarter of the total and occupied approximately 65 per cent of the land. Their ranks, in both cases, contained a wide range of ability but undoubtedly included the most prosperous, resilient, resourceful, and innovative agricultural producers, accustomed and attuned to making the most of market opportunities. They were, however, outnumbered by a mass of petty producers, deficient both in land and capital, whose prime economic objective was the deployment of labour in order to secure subsistence rather than the harnessing of capital to pursue profit. In Ireland - where $2 / 3$ hectare of potatoes yielded sufficient kilocalories to feed a family for a year - those holding 2 hectares or less outnumbered those holding more by well over three to one. In England, where it took at least $2^{1 / 2}$ hectares of grain to meet the equivalent kilocalorie requirements of a family for a year, those holding about 5 hectares or less similarly made up more than three-quarters of the total. In both agrarian economies a substantial majority of occupiers was crammed onto a small proportion of the land -35 per cent of the total area in England and a mere 15 per cent in potato-cultivating and consuming Ireland. In both societies this depressed real wages, resulted in much agricultural 
under- and un-employment, and further eroded the incomes of a growing majority of rural households.

These are 'bottom heavy' farm structures and in both it was the smallholding subsistence sector of cottiers and semi-landless labourers which had expanded most ominously as rural households multiplied in number. Nuptiality and marital fertility rates were in fact higher among labourers than farmers in Pre-Famine Ireland (Cousens, 1965). The growing cheapness and abundance of the surplus labour they supplied to commercial producers helped raise and bolster land productivity within the market-orientated sector. In England, grain yields obtained on the most intensively managed early fourteenth-century demesnes were not bettered until the eighteenth century (Campbell \& Overton, 1993). After allowance for different land qualities, crop yields per hectare in Pre-Famine Ireland were broadly comparable with those then being obtained by capitalist farmers in England (Ó Gráda, 1993: 71-72). On the carefully considered verdict of Cormac Ó Gráda (1993: 78), 'this kind of agricultural progress, in its implications for income shares, was uneven development with a vengeance'. It was born out of 'too much labour, not enough capital, not enough land' (Ó Gráda, 1993: 67). A broadly similar verdict can be passed upon the deep problems facing agriculture and the wider economy in Pre-Plague England (Campbell, 2005). Moreover, these aggregate figures understate the acuteness of the problem in those regions where morcellation had made greatest progress.

\section{The land market as a source of morcellation}

The petty holdings whose sheer numbers so imbalanced these land-holding structures were the product of a triad of processes: piecemeal reclamation, division of property between heirs, and the land market. Economic survival for smallholders everywhere depended upon possession of family and land. Providing for children was therefore a priority. Creating new holdings by reclamation from the waste was one way of achieving this. Partible inheritance was another. The custom had an obviously fragmenting effect upon landholdings whenever rates of natural increase were high. Its divisive effects were the more profound because it was normal practice to divide each component land parcel equally among all the heirs (e.g. Baker, 1964; Campbell, 1980). Even primogeniture was likely to result in subdivision under conditions of population growth since parents usually endeavoured to make at least some landed provision for non-inheriting children. A gift of assarted land might be used for this purpose but more commonly younger children were settled on smallholdings either hived off from the main holding or obtained for the purpose by lease or purchase. At Sedgeford in Norfolk, 'a great deal of the fragmentation of holdings that can be traced through the thirteenth century court rolls and surveys was the result of the transfer of land 
by tenants in order to provide for non-inheriting sons or daughters' (Williamson, 1984: 100). In a demographic situation where successive generations were expanding in size the net effect of all forms of inheritance was therefore a progressive division of both parcels and holdings. Subdivision, in turn, facilitated growth of a land market.

Although land markets provided an instrument whereby the divisiveness of inheritance could be counteracted through consolidation of plots and holdings, in both Pre-Plague England and Pre-Famine Ireland their net effect, in the main, was to reinforce division. Indeed, their effects were all the more profound because, whereas inheritance divided land between kin (with the possibility that it might eventually be re-united), land transactions permanently alienated land from a family holding usually to non-kin. Such transactions offered subsistence producers the opportunity to acquire additional land, when they had the resources to do so, as well as a means of disposing of it when necessity or circumstance required. By easing access to land they also lowered the threshold to new household formation. Hence the paradox that in both Pre-Plague England and Pre-Famine Ireland population growth rates tended to be highest in areas where holdings were smallest and living standards lowest (e.g. Harley, 1958; Cousens, 1965; Freeman, 1957: 54-8; Vanhaute, 2001).

Property rights as legally defined and defended shaped the character of the peasant land markets operating in Pre-Plague England and Pre-Famine Ireland. In medieval England tenants were either servile or free and consequently held their land, in which they enjoyed heritable rights, by villein or freehold tenure according to terms that were customary rather than contractual. Villein land was transacted in local manorial courts, where these property transfers were sanctioned, regulated, and recorded by manorial lords and their agents: freehold land was transacted by private charter, according to the common law of the realm, and disputes over its ownership were mainly resolved in royal courts. By the early fourteenth century there were roughly equal amounts of villein and freehold land, although they were unequally distributed across the country (Campbell, 2005: 24-44). As yet very little land, most of it former demesne, was held by leasehold and the property rights of lessees were poorly defined and defended. Freehold land was therefore the most sought after and actively transacted (it can be quantified and tracked using Feet of Fines: Davies \& Kissock, 2004). It could be acquired and held without any taint of servility and bought and sold with little if any seigniorial interference (see the essays contained in Smith, 1984b; Harvey, 1984; Razi \& Smith, 1996; Britnell, 2003). The market in villein land, in contrast, was subject to greater variation from manor to manor, estate to estate, and region to region in accordance with custom and estate policy (Harvey, 1984; 2003). 
Compared to Pre-Plague England, property rights in Pre-Famine Ireland were altogether more modern and uniform. All tenants were free, nominally equal under the law (especially following repeal of the last of the Penal Laws in 1793 and Catholic emancipation in 1829), and invariably held their lands by some sort of leasehold, either directly from a landed proprietor or indirectly from an intermediate tenant or 'middleman' (see Dickson, 1979, for the merits and demerits of subletting through 'middlemen'). Unlike English villeins and freeholders, Irish tenants had no inviolable heritable right to the land that they occupied - although many believed they should have - but held it, instead, contractually in return for rent and in accordance with the terms of their lease. Typically lease contracts were granted to 'a named tenant, his heirs and assigns' for a period of time that was either definite (i.e. a stated number of years) or indefinite (e.g. in perpetuity or for the duration of a stated number of named lives) and for a rent that was specified. Substantial tenants with the most defensible leasehold titles had written contracts, but the mass of minor tenants held at will with nothing more than an oral contract.

Few landlords of modest means could afford to pass by the opportunity created by a rising demand for holdings to raise their rental incomes by re-letting land in ever-smaller lots for shorter terms and higher rents. Nevertheless, they could only do so when the terms of existing leases expired. On the Earl of Gosford's estate in County Armagh, for instance, rent increases on holdings re-let during the inflationary Napoleonic War period were often of the order of 150 per cent. The problem for Lord Gosford was that only 40 per cent of the estate was eligible for re-letting during this entire period due to the very long leases which had been granted in the mid-eighteenth century (Thompson \& Tierney, 1976). Tenants on the remaining 60 per cent of the estate experienced no rental increases and were able, therefore, to appropriate to themselves the whole of the increment in land values. They did this by subdividing and subletting their holdings to others in return for the full rack rent (i.e. the current equilibrium market price for the land as determined by demand and supply). As studies of counties Cork and Tipperary demonstrate (Donnelly, 1975; Power, 1993: 119-173), this phenomenon was widespread and only those landlords who maintained tight managerial control of their estates were able to prevent it. The incentive for opposing morcellation was that substantial tenants were less likely to default on their rents and were more conducive to maintenance of social control and favourable landlord-tenant relations. It was, however, only the greatest landlords who could afford to adopt such a strategy.

Subdivision and subletting land either licitly or illicitly were therefore the principal means by which the mounting demand for holdings in Pre-Famine Ireland was gratified. Since land and family were the only guarantors of subsistence in a society 
lacking any form of institutional welfare until the 1838 Poor Law, competition between prospective tenants for holdings could be intense. Unsurprisingly, those most exposed to the inexorable workings of the leasehold market were the growing multitude of poor farmers and cottiers who, lacking both capital and credit, were in the weakest position to negotiate terms, and characteristically ended up holding land as tenants-atwill in return for the full rack rent. More vulnerable still were the army of agricultural labourers, who provided for their families by renting conacre plots from farmers on 11 -month contracts in return for a heavy labour rent ${ }^{1}$. This arrangement, which placed the labourer in a servile position relative to the farmer, was integral to how substantial commercialised farmers recruited and remunerated a labour force (Hoppen, 1989: 3359; Mokyr, 1983; Ó Gráda, 1993: 55-97; Dickson, 2005). In this respect, the capacity of the land market to provide an ever-increasing supply of such plots was a by-product of agrarian capitalism. Thus, it should not be imagined that the morcellation of holdings was confined exclusively to the 'peasant west': in 1841 there was not a single Irish county in which holdings of 2 hectares or less did not account for at least a quarter of total farms (Freeman, 1957: 54-58). Underpinned by such an abundant labour supply, it is hardly surprising that Irish agriculture succeeded in raising both its output and its yields between c.1770 and 1845. It did so, however, without any sustained improvement in labour productivity, which remained only half that of contemporary English agriculture with its large capitalised farms and proletarianised workforce (on productivity trends in Pre-Famine agriculture see, Ó Gráda, 1993: 56-79). Where labour was so abundant and cheap there was little incentive to substitute capital, nor was there sufficient work to keep each labourer fully and gainfully employed throughout the working year. In this worsening situation, all three factor markets were complicit.

Similar outcomes from operation of the land market can be recognised in PrePlague England, notwithstanding that the market was more segmented and, almost certainly, relatively smaller in turnover. Certainly, as prices and land values rose to their medieval peak in the second decade of the fourteenth century, there was a powerful economic imperative for those paying low and fixed rents to subdivide and sublet their holdings in order to secure to themselves the full rack rent. The many freehold tenants were in the strongest position to act in this way. The lowest head rents recorded in the 1279-1280 Hundred Rolls were for freehold land, much of which had been acquired by gentry, ecclesiastics, craftsmen, and tradesmen, who did not cultivate it themselves but acted as 'middlemen', no doubt subletting it piecemeal for terms of years in return for profit rents (Kanzaka, 2002; Barg, 1991). At Bishops Cleeve in Gloucestershire, for example, 21 individual sub-tenants held from a single free tenant

1 Conacre was a specifically Irish form of tenure whereby land was rented for the taking of a single crop, usually potatoes. 
(for this and other examples see, Campbell, 2005). Nor can substantial servile tenants have been indifferent to the advantages of sub-letting, especially as they, too, by the early fourteenth century usually paid sub-economic rents for their yardlands. Subletting also offered them a means of recruiting and remunerating farm servants. By 1315 probably at least $1 / 4$ million immiserated households must have eked out a tenuous and anonymous existence as the tenants and tied labourers of other men.

Unlike leasing, markets in freehold and villein land involved permanent alienation of land in return for a capital sum. Conveyances of freehold land were typically recorded by private charter - of which many thousands survive - and any disputes arising from the transaction could be resolved in the royal courts (Davies \& Kissock, 2004). In the early fourteenth century there was roughly as much villein as freehold land and the parallel market that developed in the former was contingent upon the sanction of the lords in whose courts it was conducted. By convention, servile tenants 'sold' villein land by surrendering it back into the lord's hands, who then re-granted it to the 'purchasing' tenant in return for an entry fine. The transaction itself was recorded in the court rolls which thereby provided proof of title (eventually lending its name to the form of English tenure known as 'copyhold'), but which rarely recorded the actual price paid for the land. Extant court rolls show that the market in villein land was most active on manors where lords had abandoned any attempt to preserve the integrity of standard villein holdings. It also thrived where individual plots rather than entire holdings were the objects of exchange, for it was one thing to buy or sell a single parcel of $1 / 4-1 / 2$ hectare and quite another to contemplate acquiring or disposing of an entire holding (Bekar \& Reed, 2003). In Norfolk, the most densely populated county by far in Pre-Plague England where morcellation had been taken to a national extreme, it is the market in individual plots that dominates the record on all manors with surviving court rolls.

The land market on the Norfolk manor of Hakeford Hall in Coltishall is documented by an unusually long and continuous series of court rolls and has been the subject of detailed study (Campbell, 1984). It is representative of the market in villein land on a small lay manor in an area of fragmented lordship and exceptionally high population density where the morcellation of tenant holdings was unusually pronounced and most lords had adopted a policy of licensing rather than opposing conveyances between tenants (other studies of the market in villein land on East Anglian manors include Hudson, 1921; Campbell, 1980; Smith, 1984a; Williamson, 1984; Schofield, 1997; 2008). Probably there were only about 85 hectares of villein land on this manor, of which, on average between 1280 and 1349, 2-21/2 hectares were bought and sold each year (Table 9.2): a turnover rate of about 2.5 per cent per annum (van Bavel, 2004). Most of the transactions were between non-kin and involved a single piece 
of land of less than 0.2 hectares. In a quiet year there might be just four or five such transactions but in exceptional years, at times of acute economic and demographic stress as in 1295, 1316, and 1349, the number could be five to eight times greater. More impressively, over any given 25-year period between 200 and 300 unique individuals are recorded in the court rolls as having transacted land. Evidently, this was a land market in which most of the manor's tenants participated at one time or another.

Table 9.2. The land market on the manor of Hakeford Hall, Coltishall, Norfolk, 1280-1349

\begin{tabular}{ccccccc}
\hline Period & No. of courts & No. of sales & $\begin{array}{c}\text { Area sold } \\
\text { (hectares) }\end{array}$ & $\begin{array}{c}\text { Sales per } \\
\text { court }\end{array}$ & $\begin{array}{c}\text { Area sold per } \\
\text { court (hectares) }\end{array}$ & $\begin{array}{c}\text { Area per sale } \\
\text { (hectares) }\end{array}$ \\
\hline $1280-1289$ & 19 & 55 & 11.1 & 2.9 & 0.58 & 0.23 \\
$1290-1299$ & 18 & 105 & 13.5 & 5.8 & 0.75 & 0.16 \\
$1300-1309$ & 31 & 95 & 11.6 & 3.1 & 0.38 & 0.16 \\
$1310-1319$ & 37 & 199 & 32.1 & 5.4 & 0.87 & 0.19 \\
$1320-1329$ & 27 & 183 & 25.4 & 6.8 & 0.94 & 0.16 \\
$1330-1339$ & 20 & 204 & 28.1 & 10.2 & 1.41 & 0.16 \\
$1340-1348$ & 18 & 117 & 26.4 & 6.5 & 1.46 & 0.25 \\
1349 & 4 & 41 & 13.3 & 10.3 & 3.33 & 0.35 \\
\hline $1280-1349$ & 177 & 1,015 & 164.3 & 5.7 & 0.93 & 0.19 \\
\hline & No. of trans- & who bought & $\%$ who sold & $\%$ who bought, & $\%$ making & $\%$ making \\
& actors & only & only & sold & a net gain & a net loss \\
\hline $1280-1304$ & 185 & 47 & 33 & 20 & 58 & 42 \\
$1305-1329$ & 318 & 42 & 34 & 24 & 52 & 48 \\
$1330-1354$ & 333 & 42 & 36 & 22 & 52 & 48 \\
\hline
\end{tabular}

Source. CAMPBELl (1984: 110, 131-2).

If annually the turnover of land on this manor was small (by the 1470s it had grown at least six-fold), cumulatively it was considerable (Campbell, 1975: 379). Between 1275 and 1348 almost a thousand separate inter vivos transactions transferred the ownership of over 150 hectares of land; this should be compared with the 144 post mortem transfers recorded in the same courts and the 175 hectares which thereby changed hands through inheritance. The amount of land transferred inter vivos therefore fell not far short of that transferred post mortem. Moreover, whereas only 40 per cent of post mortem transfers resulted in the division of holdings, all land transactions altered the existing distribution of property ownership. Over time, because significantly more individuals appeared in court to buy than to sell land (Table 9.2), the net effect of the market was to spread the ownership of land more 
widely. Harvest conditions plainly made a big difference to how individuals used the market. When harvests were good, as for example around 1300 and in the 1330s, the market was crowded with individuals endeavouring to convert their meagre grain surpluses into extra parcels of land, resulting in a marked excess of buyers over sellers. Conversely, when harvests were bad and economic conditions were difficult, as most conspicuously in the 1320 s and late 1340 s, far fewer individuals could afford to buy whereas many more found it necessary to sell. In effect, individuals were using the market as a means of weathering hard times (Bekar \& Reed, 2003). Nevertheless, they paid a steadily rising premium for doing so since the terms of trade were weighted against those entrapped into buying land in a seller's market and then selling it in a buyer's. No doubt it was as much for this reason as the application of partible inheritance that holdings on this manor grew steadily smaller (Table 9.3).

Table 9.3. Manor of Hakeford Hall, Coltishall: Size distribution of villein holdings recorded by obituaries, 1275-1299 and 1349-1350

\begin{tabular}{lcc}
\hline $\begin{array}{c}\text { Size of holding } \\
\text { (hectares) }\end{array}$ & $\begin{array}{c}\text { \% of total holdings } \\
1275-99(N=34)\end{array}$ & $\begin{array}{c}\text { \% of total holdings } \\
1349-50(N=86)\end{array}$ \\
\hline$>6.4$ & 3 & 0 \\
$3.2-6.4$ & 9 & 0 \\
$1.6-3.2$ & 24 & 12 \\
$0.8-1.6$ & 18 & 17 \\
$<0.8$ & 47 & 71 \\
\hline Mean size (hectares) & 1.3 & 0.7 \\
\hline
\end{tabular}

Source. CAMPBeLl (1984: 105).

The change in the distribution of villein land on this manor produced by the combination of inter vivos and post mortem land transfers can be charted by comparing the sizes of the 34 holdings recorded by obituaries during the quartercentury 1275-1299 with the 86 holdings recorded by obituaries in the plague year of 1349-1350. As Table 9.3 shows, the mean amount of villein land owned at death was roughly halved during the 50 years or so prior to the Black Death. By the time the latter struck, the privileged minority of tenants who had once held at least $31 / 4$ hectares had vanished, while the proportion holding $3 / 4$ hectare or less had grown by over 50 per cent. Undoubtedly, many of these tenants held additional land from other lords and by other tenures, nevertheless, since that too must have been subject to similar processes of attrition, there is no escaping the fact that a clear majority of tenant households were becoming depressed into the ranks of the semi-landless. In fact, it is difficult to imagine how much further the process of morcellation could have progressed. Efforts by a few enterprising individuals to engross land were not 
unknown but did not endure beyond their lifetimes. As holdings were steadily eroded in size so, too, plots were further subdivided in order to supply the market with the small parcels that were most in demand and with which owners could most afford to part. Fields, therefore, became as fragmented as holdings, which did little to enhance the efficiency and productivity of the labour applied to them.

These trends were general phenomena and may be observed on most other Norfolk manors for which relevant records are extant. On the nearby manor of Hevingham between 1274 and 1299, three-quarters of all obituaries recorded 3/4 hectare or less of land, and a detailed extent of the prior of Norwich's manor of Martham in 1292 records 376 property owners where a century or more before there had been 107 , 63 per cent of whom held less than $3 / 4$ hectare and only 5 per cent $3 \frac{1}{4}$ hectares or more (Campbell, 1981). Since active peasant land markets existed on both these manors, it seems almost certain further morcellation occurred over the next half century. Elsewhere in the county, at Gressenhall and Sedgeford, land markets had a similarly fragmenting effect upon holdings (Williamson, 1984), and the same tendency has been observed on the Suffolk manors of Redgrave and Hinderclay (Smith, 1984a; Smith, 1996; Schofield, 2008). By sustaining the multiplication of holdings operation of these markets served to underpin Norfolk's status as England's most densely populated county, supporting an average of at least 170 people per square mile $\left(66\right.$ per $\left.\mathrm{km}^{2}\right)$ at the close of the thirteenth century and probably double that density in its most congested districts (Campbell, 2008: 29; Cornford, 2002). Some 41/2 centuries later - by which time Norfolk had become synonymous with agrarian capitalism the county's population was some 30 per cent smaller (Campbell, 2008: 26).

Lords, of course, profited in a modest way from the land market via the entry fines that it generated and from penalties imposed upon those who sold or leased land without the court's sanction (on small manors with limited jurisdiction, like that of Hakeford Hall, these revenues might, however, be offset by the costs of holding the courts and hiring a clerk to record their business). Lords may also have gained from the growing numbers of rent-paying tenants on their manors, provided that the latter did not become so impoverished that they fell into rental arrears. For lords with demesnes to cultivate, however, there was a real economic advantage in the expanding supply of an ever-cheaper source of labour so desperate for work. Increasingly, demesne managers substituted hired for servile labour and adopted such labour-intensive tasks as marling, manuring, weeding, fodder cropping, and multiple ploughings (Campbell, 1983; 2010). By these methods they sometimes raised grain yields to levels that would not be surpassed until the eighteenth century (Campbell, 1983; 1991). They therefore had a vested interest in perpetuating the symbiosis that had come about between 
large demesne farms producing surpluses for sale and small peasant holdings selling surplus labour to demesnes (and anyone else who would employ it).

Without active markets in land, labour, and credit Norfolk's multitude of small holders and near-landless agricultural labourers could not have survived. Yet unrestrained working of these markets was also responsible for progressive erosion of that population's material conditions of life. Rural poverty was patently more acute and more general by 1315 than it had been in 1270. Since the 1290s good and bad harvests had elicited increasingly exaggerated surges of land purchases and sales due to their differential impact upon the capacity of small holders to feed themselves, pay their rents, and meet their credit obligations (Hudson, 1921; Campbell, 1984). In hard times peasants sacrificed the very means of their livelihoods. Similar stresses and strains are reflected in the payment of heriots on the bishopric of Winchester's estate in southern England (Postan, 1973; Harvey, 1991: 8-9). During the agrarian crises of 1315-1322 and 1346 seigniorial and Crown courts were swamped with business. Norfolk peasants may have been 'rampant individualists, highly mobile both geographically and socially, economically 'rational', market-oriented and acquisitive, ego-centred in kinship and social life' (Macfarlane, 1978: 163) but this had not resulted in the creation of agrarian capitalism (Campbell, 1984: 91). Factor markets had colluded in thwarting such an outcome. Instead, the land had become congested with a smallholding tenantry whose existence it was beyond the power, inclination, and imagination of lords to remove. Nor would the occupying peasantry have brooked any change in the status quo, for any attempt to consolidate holdings would have struck at their very livelihoods and deprived them of the one resource land - most essential for their subsistence and survival.

\section{Remedies to morcellation}

What remedies were there once morcellation on this scale had set in? Probably the most extreme measure was eviction and consolidation by improving landlords bent upon raising the rental yield of their estates. Yet landlords in Pre-Plague England had no such concept of 'improvement' and in practice never evicted, while those PreFamine Irish landlords who did subscribe to the concept found it imprudent to act for fear of the potentially violent opposition of the occupying tenantry (Beames, 1983). In both situations, the political and humanitarian obstacles to consolidation were too great to be overcome. Governments might have succeeded where individual landlords hesitated to act, but direct political intervention in agriculture was also alien to these two societies. Not until the 1880s did Ireland, via a succession of land acts and establishment of the Congested Districts Board, became the object of a pioneering and far-reaching government policy of land reform aimed at rationalising holdings 
and plots, reforming rents and tenures, transforming proprietorship, and improving agrarian infrastructure (Solow, 1971). Such initiatives were, however, inconceivable before the late nineteenth century and always politically difficult to implement because of the many vested landed interests.

Prevention rather than cure was, in fact, generally the more practicable strategy. In Pre-Black Death England such major landlords as the abbots of Ramsey and Glastonbury successfully deterred morcellation of villein holdings by outlawing subdivision, opposing sub-letting, and imposing high entry fines intended to exclude those with little capital or credit from acquiring land (Fox, 1996; Raftis, 1997). Their motive for doing so seems to have been to maintain a capital-rich class of substantial tenants who had a vested interest in preserving the manorial status quo. Nevertheless, as the warden and fellows of Merton College Oxford discovered on their manor of Thorncroft in Surrey, this was not a policy enforcable upon tenants holding by free tenure (Evans, 1996: 236-237). Nor, once morcellation had set in, was there much prospect of ever retrieving the situation. In practice, most Pre-Plague landlords acquiesced with the operation of a land market and made the most of the revenuemaking opportunities that monitoring, recording, and policing post mortem and inter vivos transfers of villein land offered them. Tenurial reform may have been acutely needed but its social cost was too high, as yet there was no clear concept of what was required or how to bring it about, and in the absence of a dynamic urban sector there was almost nowhere for displaced tenants to $\mathrm{go}^{2}$.

Pre-Famine Irish landlords had access to more ideas and knowledge about what kinds of action might prove effective and consequently were less impotent. Many attempted to retrieve, if not entirely remedy the deteriorating tenurial situation, by taking a more active interest in management of their estates and recruiting experienced and professional agents to assist them. For instance, in 1821 the Earl of Gosford employed the Scottish land surveyor, William Greig, to survey his estate and recommend how it might be got to yield a higher and more reliable rental income (Crawford, 1976). Greig advised Gosford to oppose and outlaw all further subdivision and subletting; enter, whenever possible, into direct tenurial relations with the occupying tenants; embark upon a programme of piecemeal consolidation as and when the opportunities arose; and give active encouragement to the most promising tenants. Gosford chose to ignore most of this advice, finding an advantageous marriage easier to negotiate and more financially rewarding than reform of the degenerate tenures on his congested estate. Besides, Greig's advice was designed to contain rather than resolve the fundamental problem of rural overcrowding.

$2 \quad$ For the Pre-Plague stagnation of London's economy see KeEnE (1984); for the strain placed by impoverished migrants upon Norwich's economy see RUTLEDGE (1988 and 2004). 
Nor was promotion of proto-industry more than a palliative to the scourge of rural un- and under-employment and low household incomes, for it actually facilitated and fed off the morcellation of holdings. Lord Gosford's estate lay in the heart of Ireland's linen-producing countryside where farmer-weavers had bid up rents and driven down holding sizes to levels uneconomic for commercial agriculture. By the 1840 s barely a holding in the linen counties was larger than $12^{1} \frac{1}{2}$ hectares and almost half were 2 hectares or less (Freeman, 1957: 54-55). Any failure of industrial employment (as occurred from 1825 with the advent of mechanised flax spinning) or reduction in industrial wages (as unemployed spinners turned en masse to weaving) therefore spelled ruin for those attempting to derive a subsistence from these inadequate holdings. The lesson is clear, only for as long as industry prospered could such smallholdings remain viable, yet the more prosperous proto-industry became and the greater the subsidy it provided to rural incomes, the smaller that holdings shrank (cf. the Flemish linen-textile area: Vanhaute, 2001).

Insofar as a panacea to morcellation existed, it lay in a far-reaching transformation of the entire socio-economic status quo, since alteration of the context within which factor markets operated changed their outcomes. The catalyst in both fourteenthcentury England and nineteenth-century Ireland was a massive and biologically induced reduction of population levels precipitated, respectively, by plague and potato blight (Herlihy, 1997; Solar, 1989). England's population was cut back by about half between 1315 and 1375 and Ireland's by almost as much between 1841 and 1901. In both cases, further demographic decline and stagnation persisted for some time thereafter, allowing holdings to shrink in number and grow in size. The more opportunistic tenants began to make strategic use of the land market, marriage, and inheritance to accumulate land on a significant scale, paving the way for the emergence of substantial commercial farms several generations later (Campbell, 1981; Whittle, 2000: 85-224; Spufford, 1965). Partly because it was the labourers and cottiers who had been most vulnerable and who therefore perished in greatest numbers, the myriad of petty holdings soon became a thing of the past. In Ireland between 1847 and 1852 the number of holdings of 2 hectares or less fell by 40 per cent; over the same period total holdings fell by 25 per cent (Kennedy et al., 1999: 163).

Such trends are unsurprising given the massive alteration in the ratios of population to land and the ongoing demographic malaise in both societies, and merely highlight how much the outcome of inheritance practices and land markets depended upon the context and circumstances within which they operated. Much more to the point is whether processes of engrossment, once initiated, persisted when population growth was eventually resumed (as seems to have been the case in sixteenth-century Norfolk: Whittle, 2000), or whether holdings built up during eras of demographic recession 
in turn fragmented as morcellation became again predominant (as was the case of much of the proto-industrialising north and west of England: Outhwaite, 1986: 8-12). Exactly what combination of factors tipped the balance in favour of continued agglomeration or renewed morcellation remains one of the greatest enigmas in British agrarian history and is critical to understanding what caused factor markets to promote agrarian capitalism with its large farms and proletarianised labour force rather than commercialised subsistence production rooted in an entrenched class of petty occupiers.

\section{From morcellation to agglomeration and 'peasants' to 'capitalists'}

Pre-Plague England and Pre-Famine Ireland exemplify the capacity of land markets, in combination with credit and labour markets, to engender a progressive morcellation of holdings and build up of population pressure on the land, with all the adverse implications this then had for living standards and economic growth. Large commercial farms existed and thrived in both situations but their co-existence with a multiplying mass of petty holdings ensured that there could be no general breakthrough to agrarian capitalism and rising total factor productivity in agriculture and no lasting resolution of the Ricardian and Malthusian dilemmas that haunted these and other similarly constituted agrarian economies. The late emergence of fully-fledged agrarian capitalism in so much of Europe implies that this type of scenario was by no means unusual. Certainly, it is an issue that awaits more systematic investigation. In the interim it is possible to suggest four pre-conditions which needed to be in place before factor markets were able to promote the kinds of efficient economic outcomes that economists believe they should.

First, there were improvements to the legal definition of property rights and rules governing their transfer. Examples include the protection of lessees against the thirdparty interests of lessors, development of entail to exclude females from inheriting, and establishment of the legal right to bequeath land as well as chattels by will so that less and less land was subject to the application of customary rules of inheritance. Separating personal status from tenure also served to de-partition land markets, enabling free tenants to acquire and hold former villein land by copyhold tenure without incurring the taint of servility. Of related importance were developments that lowered the transactions costs of buying, selling, and leasing land. These included the availability of cheaper and better legal services, quicker and easier resolution of disputes, effective enforcement of contracts (such as clauses in leases which forbade subletting), and, especially, lower interest rates. 
Second, the rent-seeking opportunities so conducive to subdivision and subletting needed to be eliminated. Here, relevant measures included closer supervision of tenures by proprietors and their agents, replacement of customary with contractual tenancies, the charging of competitive market rents and high entry fines, and introduction and enforcement of legal clauses in lease contracts forbidding subletting. Introducing and implementing such measures depended upon landlords and their agents getting tougher and adopting a more commercial approach towards estate management and they needed to be equipped with better information about how to do this.

Third, the returns to commercial agriculture had to get better. Since markets were the mother of profit-seeking behaviour, the growth of concentrated urban demand provided farmers with a major incentive to invest, innovate, specialise, pursue profits, and expand their enterprises. Equally importantly, large cities drove up the economic rent for commercial relative to subsistence production and, by raising the costs of subsistence, discouraged proto-industrialisation within their immediate hinterlands. The early breakthrough to agrarian capitalism in the south and east of England owed much to the precocious growth of London; at a slightly later date the rise of Dublin had a similar influence upon much of Leinster (and the same undoubtedly held true of highly urbanised Holland). Part of this process necessarily involved structural economic change so that population growth was increasingly absorbed by expansion of employment outside of rather than within agriculture. Dynamic cities also provided a destination for those dispossessed of land and displaced from the countryside.

Fourth, rampant population growth needed to be curbed by adoption of preventative demographic measures. Increased emigration overseas and rural to urban migration both helped relieve pressure upon the land, provided that suitable opportunities existed. Within the countryside, a relative shift from biological to economic marriage - nowhere taken further than in Post-Famine Ireland - helped to restrain rates of natural increase. Introduction of institutionalised welfare likewise served to reduce the overwhelming dependence of the poor upon large families as the best and often only insurance against hard times (Solar, 1997).

Much, therefore, had to change across a broad front before agglomeration rather than morcellation became the predominant outcome of land markets. Moreover, the experience of Pre-Plague England and Pre-Famine Ireland indicates that what determined which of these alternatives prevailed was less the precise rights and rules governing land markets (for these were very different in Pre-Plague England and Pre-Famine Ireland) than the general economic context within which those markets operated. The nature of that context throughout the greater part of Western Europe during the pre-industrial period suggests that on balance land markets were probably 
more a hindrance than a help to economic growth until the nineteenth century and sometimes even later.

\section{Bibliography}

Allen, Robert C. (2001), 'The Great Divergence in European Wages and Prices from the Middle Ages to the First World War', Explorations in Economic History, 38, p. 411-447.

Allen, Robert C. (2000), 'Economic Structure and Agricultural Productivity in Europe, 1300-1800', European Review of Economic History, 3, p. 1-25.

BAKer, Alan R. H. (1964), 'Open Fields and Partible Inheritance on a Kent Manor', Economic History Review, 2nd series, 17, p. 1-23.

BARG, M. A. (1991), 'The Social Structure of Manorial Freeholders: an Analysis of the Hundred Rolls of 1279', Agricultural History Review, 39, p. 108-115.

VAN BAvel, Bas J. P. (2001), 'Land, Lease and Agriculture: the Transition of the Rural Economy in the Dutch River Area from the Fourteenth to the Sixteenth Century', Past and Present, 172, p. 3-43.

van Bavel, Bas J. P. (2004), 'Structures of Landownership, Mobility of Land, and Farm Sizes: Diverging Developments in the Northern Parts of the Low Countries, c. 1300c. 1650', in Bas J. P. van Bavel \& Peter C. M. Hoppenbrouwers (eds), Landholding and Land Transfer in the North Sea Area (Late Middle Ages-19th Century), Turnhout, Brepols, CORN publication series 5, p. 131-148.

van Bavel, Bas J. P., De Moor, Tina \& van Zanden, Jan Luiten (2009), 'Introduction: Factor Markets in Global Economic History', Continuity and Change, 24, p. 9-21.

Beames, Michael (1983), Peasants and Power: the Whiteboy Movements and their Control in Pre-Famine Ireland, Brighton, Harvester Press.

Bekar, Cliff T. \& Reed Clyde G. (2003), 'Open Fields, Risk, and Land Divisibility', Explorations in Economic History, 40, p. 308-325.

Bekar, Cliff T. \& Reed, Clyde G. (2009), 'Risk, Asset markets and Inequality: Evidence from Medieval England', University of Oxford, Discussion Papers in Economic and Social History, 79, Oxford, p. 1-22.

Bourke, P. M. Austin (1965), 'The Agricultural Statistics of the 1841 Census of Ireland: a Critical Review', Economic History Review, 2nd series, 18, p. 376-391.

Britnell, Richard H. (ed.) (2003), The Winchester Pipe Rolls: Studies in Medieval English Economy and Society, Woodbridge, Boydell Press.

Campbell, Bruce M. S. (1975), 'Field Systems in Eastern Norfolk during the Middle Ages: a Study with Particular Reference to the Demographic and Agrarian Changes of the Fourteenth Century', unpublished doctoral thesis, University of Cambridge.

Campbell, Bruce M. S. (1980), 'Population Change and the Genesis of Commonfields on a Norfolk Manor', Economic History Review, 2nd series, 33, p. 174-192.

Campbell, Bruce M. S. (1981), 'The Extent and Layout of Commonfields in Eastern Norfolk', Norfolk Archaeology, 38, p. 18-26. 
Campbell, Bruce M. S. (1983), 'Agricultural Progress in Medieval England: some Evidence from Eastern Norfolk', Economic History Review, 2nd series, 36, p. 26-46.

Campbell, Bruce M. S. (1984), 'Population Pressure, Inheritance, and the Land Market in a Fourteenth-Century Peasant Community', in Richard M. Sмітн (ed.), Land, Kinship and Lifecycle, Cambridge, Cambridge University Press, p. 87-134.

Campbell, Bruce M. S. (1991), 'Land, Labour, Livestock, and Productivity Trends in English Seigniorial Agriculture, 1208-1450', in Bruce M. S. CAMPBell \& Mark Overton (eds), Land, Labour and Livestock: Historical Studies in European Agricultural Productivity, Manchester, Manchester University Press, p. 144-182.

Campbell, Bruce M. S. (2000), English Seigniorial Agriculture, 1250-1450, Cambridge, Cambridge University Press.

Campbell, Bruce M. S. (2005), 'The Agrarian Problem in the Early Fourteenth Century', Past and Present, 188, p. 3-70.

CAmpBell, Bruce M. S. (2008), 'Benchmarking the Medieval Economy: England, Wales, Scotland, and Ireland circa 1290’, Economic History Review, 61, p. 896-948.

Campbell, Bruce M. S. (2009), 'Factor Markets in England before the Black Death', Continuity and Change, 24, p. 79-106.

Campbell, Bruce M. S. (2010), 'Agriculture in Kent in the High Middle Ages', in Sheila Sweetinburgh (ed.), Later Medieval Kent 1220-1540, Woodbridge, Boydell Press and Kent County Council.

Campbell, Bruce M. S. \& Overton, Mark (1993), 'A New Perspective on Medieval and Early Modern Agriculture: Six Centuries of Norfolk Farming c.1250-c.1850', Past and Present, 141, p. 38-105.

Clark, Gregory (2007), 'The Long March of History: Farm Wages, Population, and Economic Growth, England 1209-1869', Economic History Review, 2nd series, 60, p. $97-$ 135.

Cornford, Barbara (2002), Medieval Flegg: Two Norfolk Hundreds in the Middle Ages: East and West Flegg, 1086-1500, Dereham, Larks Press.

Cousens, Stuart H. (1965), 'The Restriction of Population Growth in Pre-Famine Ireland', Proceedings of the Royal Irish Academy, Section C, 64:4, p. 85-99.

Crawford, William H. (ed.) (1976), General Report on the Gosford Estates in Co. Armagh, 1821 by William Greig, Belfast, HMSO.

DAvies, Michael \& Kissock, Jonathan (2004), 'The Feet of Fines, the Land Market and the English Agricultural Crisis of 1315 to 1322', Journal of Historical Geography, 30, p. 215-230.

Dickson, David (1979), 'Middlemen', in Thomas Bartlett \& David W. Hayton (eds), Penal Era and Golden Age: Essays in Irish History, 1690-1800, Belfast, Ulster Historical Foundation, p. 162-185.

Dickson, David (2005), Old World Colony: Cork and South Munster 1630-1830, Cork, Cork University Press.

Donnelly, James S. (1975), The Land and the People of Nineteenth-Century Cork: the Rural Economy and the Land Question, London and Boston, MA, Routledge and Kegan Paul. 
Dowling, Martin W. (1997), 'Prices and Wages in Ireland, 1700-1850', Irish Economic and Social History, 24, p. 62-104.

Evans, Ralph (1996), 'Merton College's Control of its Tenants at Thorncroft 1270-1349', in Zvi Razi \& Richard M. Sмiтн (eds), Medieval Society and the Manor Court, Oxford, Clarendon Press, p. 199-259.

FERrer-Alòs, L. (this volume), 'Mechanisms for the Creation and Reproduction of a Land Ownership Structure in Central Catalonia from the Fourteenth-Nineteenth Centuries'.

Fox, Harold S. A. (1996), 'Exploitation of the Landless by Lords and Tenants in Early Medieval England', in Zvi Razi \& Richard M. Sмith (eds), Medieval Society and the Manor Court, Oxford, Clarendon Press, p. 518-568.

Freeman, Thomas W. (1957), Pre-Famine Ireland: a Study in Historical Geography, Manchester, Manchester University Press.

Harley, J. Brian (1958), 'Population Trends and Agricultural Developments from the Warwickshire Hundred Rolls of 1279', Economic History Review, 2nd series, 11, p. 8-18.

Harvey, Barbara F. (1991), 'Introduction: the "Crisis” of the Early Fourteenth Century', in Bruce M. S. Campbell (ed.), Before the Black Death: Studies in the "Crisis" of the Early Fourteenth Century, Manchester, Manchester University Press, p. 1-24.

Herlihy, David (ed.) (1997), The Black Death and the Transformation of the West, ed. and intro. Samuel K. CoHn, Jr., Cambridge, Cambridge, MA, and London, Harvard University Press.

Hoppe, Göran \& Langton, John (1994), Peasantry to Capitalism: Western Östergötland in the Nineteenth Century, Cambridge, Cambridge University Press.

Hoppen, K. Theodore (1989), Ireland since 1800: Conflict and Conformity, London, Longman.

Hoppenbrouwers, Peter \& van Zanden, Jan Luiten (eds) (2001), Peasants into Farmers? The transformation of Rural Economy and Society in the Low Countries (Middle Ages19th Century) in Light of the Brenner Debate, CORN publication series 4, Turnhout, Brepols.

Hudson, Rev. William (1921), ‘The Prior of Norwich's Manor of Hindolveston: its Early Organisation and Rights of the Customary Tenants to Alienate their Strips of Land', Norfolk Archaeology, 20, p. 179-214.

KanZAKA, Junichi (2002), 'Villein Rents in Thirteenth-Century England: an Analysis of the Hundred Rolls of 1279-1280', Economic History Review, 2nd series, 55, p. 595-618.

KeEnE Derek J. (1984), 'A New Study of London before the Great Fire', Urban History Yearbook 1984, p. 11-21.

Kennedy, Liam, Ell, S. Paul, Crawford, E. Margaret \& Clarkson, Leslie A. (1999), Mapping the Great Irish Famine: a Survey of the Famine Decades, Dublin, Four Courts Press.

Macfarlane, Alan (1978), The Origins of English Individualism: the Family, Property and Social Transition, Oxford, Blackwell.

MокуR, Joel (1983), Why Ireland Starved: a Quantitative and Analytical History of the Irish Economy, 1800-1850, London, George Allen and Unwin. 
Ó GRÁDA, Cormac (1993), Ireland Before and After the Famine: Explorations in Economic History, 1800-1925, Manchester, Manchester University Press.

Ó GrádA, Cormac (1994), Ireland: a New Economic History 1780-1930, Oxford, Clarendon Press.

Outhwaite, R. Brian (1986), 'Progress and Backwardness in English Agriculture, 15001650’. Economic History Review, 2nd series, 39, p. 1-18.

PAGE, Mark (2003), 'The Peasant Land Market on the Estate of the Bishopric of Winchester before the Black Death', in Richard H. BRITnell (ed.), The Winchester Pipe Rolls: Studies in Medieval English Economy and Society, Woodbridge, Boydell Press, p. 61-80.

Palmer, Robert C. (1985), 'The Economic and Cultural Impact of the Origins of Property: 1180-1220', Law and History Review, 3, p. 375-96.

Postan, Michael M. (with Jan Z. Titow) (1973), 'Heriots and Prices on Winchester Manors with Statistical Notes on Winchester Heriots by J. Longden', in Michael M. Postan, Essays on Medieval Agriculture and General Problems of the Medieval Economy, London, Cambridge University Press, p. 150-185.

Power, Thomas P. (1993), Land, Politics, and Society in Eighteenth-Century Tipperary Oxford, Clarendon Press.

Raftis, J. Ambrose (1997), Peasant Economic Development within the English Manorial System, Stroud, Sutton.

Razi, Zvi \& Smith, Richard M. (eds), (1996) Medieval Society and the Manor Court, Oxford, Clarendon Press.

Rutledge, Elizabeth (1988), 'Immigration and Population Growth in Early Fourteenth-Century Norwich: Evidence from the Tithing Roll', Urban History Yearbook 1988, p. 15-30.

RutLEDGE, Elizabeth (2004), 'Norwich before the Black Death/Economic Life', in Carole RAWCLIFFE \& Richard WiLSON (eds), Medieval Norwich, London, Hambledon and London, p. $157-188$.

Schofield, Phillipp R. (1997), 'Dearth, Debt and the Local Land Market in a Late Thirteenth-Century Village Community', Agricultural History Review, 45, p. 1-17.

Schofield, Phillipp R. (2008), “ The Social Economy of the Medieval Village in the Early Fourteenth Century', Economic History Review, 61, S1, p. 38-63.

Smith, Richard M. (1984a), 'Families and their Land in an Area of Partible Inheritance: Redgrave, Suffolk 1260-1320', in Richard M. Sмiтн (ed.) (1984[b]), Land, Kinship and Lifecycle, Cambridge, Cambridge University Press, p. 35-95.

Sмiтh, Richard M. (ed.) (1984b), Land, Kinship and Lifecycle, Cambridge, Cambridge University Press.

Smith, Richard M. (1996), 'A Periodic Market and its Impact upon a Manorial Community: Botesdale, Suffolk, and the Manor of Redgrave, 1280-1300', in Zvi RAzi \& Richard M. Sмiтн (eds), Medieval Society and the Manor Court, Oxford, Clarendon Press, p. 450-481.

Solar, Peter M. (1997), 'Poor Relief and English Economic Development: a Renewed Plea for Comparative History'. Economic History Review, 2nd series, 50, p. 369-374. 
Solar, Peter M. (1989), 'The Great Famine was no Ordinary Subsistence Crisis', in E. Margaret CRAWFORD (ed.), Famine: the Irish Experience, 900-1900. Subsistence Crises and Famines in Ireland, Edinburgh, John Donald, p. 112-133.

Solow, Barbara L. (1971), The Land Question and the Irish Economy, 1870-1903, Cambridge, MA, and London, Harvard University Press.

SPufFORD, Margaret (1965), A Cambridgeshire Community: Chippenham from Settlement to Enclosure, Department of English Local History, Occasional Paper 20, Leicester.

Tawney, Richard H. (1912), The Agrarian Problem in the Sixteenth Century, London, Longmans, Green \& Co.

Thompson, F. Michael L. \& Tierney, David (1976), 'Introduction', in William H. Crawford (ed.) (1976), General Report on the Gosford Estates in Co. Armagh, 1821 by William Greig, Belfast, HMSO, p. 1-36.

Vanhaute, Eric (2001), 'Rich Agriculture and Poor Farmers: Land, Landlords and Farmers in Flanders, 18th-19th centuries', Rural History: Economy, Society, Culture, 12, p. $19-40$.

Whittle, Jane (2000), The Development of Agrarian Capitalism: Land and Labour in Norfolk 1440-1580, Oxford, Oxford University Press.

Williamson, Janet (1984), 'Norfolk: Thirteenth Century', in Paul D. A. Harvey (ed.), The Peasant Land Market in Medieval England, Oxford, Clarendon Press, p. 31-105. 